Article

\title{
GEOTECHNICAL PROPERTIES OF LATERITIC SOIL STABILIZED WITH PERIWINKLE SHELLS POWDER
}

Abiola. M. Dauda ${ }^{1}$, Joseph O. Akinmusuru ${ }^{1}$, Oluwaseun. A. Dauda ${ }^{1}$, Taiwo O. Durotoye ${ }^{1}$, and Kunle E. Ogundipe ${ }^{* 2}$ Kehinde O. Oyesomi $^{3}$

4abiola@gmail.com; Joseph.akinmusuru@covenantuniversity.edu.ng; sheunolus@yahoo.com; taiwo.durotoye@covenantuniversity.edu.ng; Kehinde.oyesomi@covenantuniversity.edu.ng

${ }^{1}$ Department of Civil Engineering, Covenant University, Ota 112233, Ogun State Nigeria.

${ }^{2}$ Department of Building Technology, Covenant University, Ota 112233, Ogun State Nigeria.

${ }^{3}$ Department of Mass Communication, Covenant University, Ota 112233, Ogun State Nigeria.

*Corresponding Author: kunle.ogundipe@covenantuniversity.edu.ng; Tel.: +234-806-237-1086

\begin{abstract}
This study used eco-friendly materials known as Periwinkle Shell Powder (PSP) in stabilizing the engineering properties of lateritic soil. Preliminary test was performed on the un-stabilized lateritic soil for the purposes of identification and classification (natural moisture content, liquid limits, plastic limits, and plasticity index). The engineering tests were conducted on the lateritic soil stabilized with additions of $(2,4,6,8$ and $10 \%)$ PSP and OPC respectively. The result showed that cement gave a progressive increase in the Maximum Dry Density (MDD) of the lateritic soil from $1875 \mathrm{~kg} / \mathrm{m} 3(2 \%)$ to $2294 \mathrm{~kg} / \mathrm{m} 3(10 \%)$ respectively. This represents $22 \%$ increase in the MDD from the un-stabilized state. For PSP, the Maximum MDD was attained at $6 \%(1974 \mathrm{~kg} / \mathrm{m} 3)$, representing $5.3 \%$ increase in MDD of the soil from the un-stabilized state. For both stabilizing agent, the Optimum Moisture Content (OMC) increases from $13.65 \%$ to $13.83 \%$ and from $11.72 \%$ to $14.41 \%$ for Cement and Periwinkle Shell Powder respectively. PSP recorded an increase of $5.6 \%$ of CBR value compared with OPC that recorded an increase of $34 \%$ CBR value. The study therefore concluded that Periwinkle Shell Powder (PSP) could be considered as good stabilizer for clayey or lateritic, and its uses as a stabilizer could also provide a big relief to the environmental pollution caused by its indiscriminate dumping.
\end{abstract}

Keywords: Periwinkle Shell Powder, Geotechnical Property, Expansive soil, Stabilization.

1. Introduction

The important nature of soils in their natural states requires that its engineering properties meet construction standards. Often time, soils encountered seasonal volume change or swelling natures in the water permeability. [1] Defined soil as the strong material on the Earth's due to weathering and organic action on the parent material. Lateritic soil can also be defined as weathered tropical or sub-tropical remaining soil, generally covered with sesquioxide rich solidifications [2]. In the same manner, [3] report that soil is characterised with high temperature and moisture content leading to intense chemical weathering that forms well graded residual soils.

Soil is used as a construction material in various building and civil engineering projects to provide structural supports to foundation. It is note-worthy to state that not all soils are suitable for construction 
in their natural states. The properties that make soils unsuitable for construction of engineering structures in their natural state are generally referred to as problematic soil [4] Problematic soils could either be expansive soil or collapsible soil which in return causes low bearing capacity in building foundation, breaking and creaking of road structures [5].

Problematic soils are characterized by clayey materials and when used for engineering purposes without treatment could result into structural cracks in building, roads and damage to underground infrastructures [6-7]. Clays exhibit generally undesirable engineering properties characterized by low shear strengths which is further lost upon wetting or other physical disturbances [8]. The problematic nature of expansive soils is peculiar in Nigeria context, because clay minerals are predominantly present in most sub-grade materials [9]. When clay is wet it has potential to expand and shrink when dried. Cohesive soils are prone to sliding because it creep over time under constant load, especially when the shear stress is approaching its shear strength. According to [10] aggregate should be free of silt content.

Lateritic soil has less than 30\% silt content, between 25-63 \% liquid limit and 5-42 \% plasticity index [1114]. On this ground, it is understandable that the geotechnical properties of lateritic soil could be improved before there usage for engineering purposes. Otherwise they are bound to cause damages when use in their natural states. Different researchers have reported that the engineering properties (permeability density and porosity) of lateritic soil could be improve through sterilization just like expansive soil [15-16]. This improvement is usually done by stabilization. Soil stabilization enhances the strength, control soil dust and ensure soil water proofing [17]. Soil stabilization is the process of elimination of swelling properties of soils to enhance its shear strength and improve its load bearing capacity.

[18] Define soil stabilization as process of chemical, mechanical, and biological means of improving soil properties therefore made the properties of soil more suitable for engineering purposes. Soil stabilisation also connote the alteration of the soil properties, this means that the three phases present in the soil are modified i.e. the solid phase which is the mineral particles, the liquid phase which denotes the moisture content of the soil and the gaseous phases, which is the void or air present in the soil are all modified in the process of soil stabilization to obtain desirable lasting properties, which are compatible with a particular application. Stabilisation method could either be by water through bonding the soil particles together, water proofing the particles or combine the two method [19].

According to [20-25] some of the previous studies used cement, lime, periwinkle, fly ash, bitumen or combination of these stabilizing agents to improve geotechnical properties of soil. Application of these stabilizing agents to a soil usually results in a stabilized soil whose materials have a higher strength, lower permeability and lower compressibility than the native un-stabilized soil. For instance, chemical stabilization for soil property improvement consists of changing the physicochemical environment around and inside clay particles, changing the nature of the water that alternately moves into and out of the voids, thus effecting behavioural changes in the soil mass as a whole. Chemical stabilization aims at making the clay require less water to satisfy the charge imbalance, making it difficult for water to move into and out of the system, flocculating the clay to cause aggromulation, and, perhaps, cementing particles together to reduce volume change.

However, in view of using a sustainable stabiliser that will be cost effective and eco-friendly [26-27] used common salt to stabilised expensive soil and noticed that the addition of $1.5 \%$ of common salt to the weight of expansive soil decreased the swelling behaviour but improve the strength quality of expansive soil, thereby made the treated soil more stabilized. 
In the same vein, researchers effort have been noticed on the use of pozzolans as partial replacement stabilizer because pozzolans are generally siliceous or/and aluminous materials which could either exist naturally like volcanic ash, opaline shale, tuff pumicite. Pozzollans can also be created artificially like the one used in this research work. Periwinkle Shell powder (PSP) obtained by the processing of empty Periwinkle shells into powder. Other artificial pozollans are pulverised coal fly ash (PFA), Metakaolin (calcined clay), ground granulated blast furnace slag (GGBS) and silica fume.

However, more authors have worked on some sustainable local content, for example [28-30] adopted up to $40 \%$ rice husk ash (RHA) in partial replacement of cement for blocks production and noticed no significant decline in strength at age $28-60$ days. [31] explored the potential of pozzolinic in palm kernel nut ash (PKNA), and came with the conclusion that $10 \%$ of palm kernel nut ash (PKNA) cloud be partially replace cement and give more durable binder compared to when cement is completely used. [32] combined a pozzolan, Pulverised Calcined Clay (PCC), and calcium hydroxide $(\mathrm{Ca}(\mathrm{OH}) 2)$, Carbide Waste $(\mathrm{CW})$, to generate $11 \mathrm{MPa}$ concrete strength after 28 day of curing. [23-25] reported that the chemical composition of PSP $\left(\mathrm{SiO}_{2}, \mathrm{Al}_{2} \mathrm{O}_{3}, \mathrm{CaO}\right.$ and $\left.\mathrm{Fe}_{2} \mathrm{O}_{3}\right)$ were above $90 \%$ which was higher than the $70 \%$ prescribed by ASTM C618. In the same manner, [33-34] studies showed an improvement on ecofriendly stabilizer (milled eggshell and Rice Husk Ash) when used to stabilized the geotechnical properties of the clayey and lateritic soil.

This study examined periwinkle shell as stabiliser that contains cementitious value that when finely grounded in a powdery form or processed into liquid could chemically react with calcium hydroxide in the presence of moisture at room temperature to form permanent insoluble compounds possessing cementitious properties. Periwinkle Shell Powder is obtained by processing periwinkle shells after the consumption of a small greenish-blue marine snail (periwinkle). The periwinkle snail is very strong and housed in a V shaped spiral shell, found in Lagos, Badagry, Port-Harcourt, Calabar, Ikot-Abasi and many other coastal communities across Nigeria.

The people in the coastal areas mainly consume the edible part of the periwinkle as sea food while disposing the shell as a waste product which could cause environmental pollution because of its indiscriminate dumping. According to [35] education constitutes the core of human development. in other to encourage local participation in the use of periwinkle shell as pozzolans and aggregate, media can play a key role in information dissemination to mass audience in order to make the message achieve desired purposes [36-37]. 


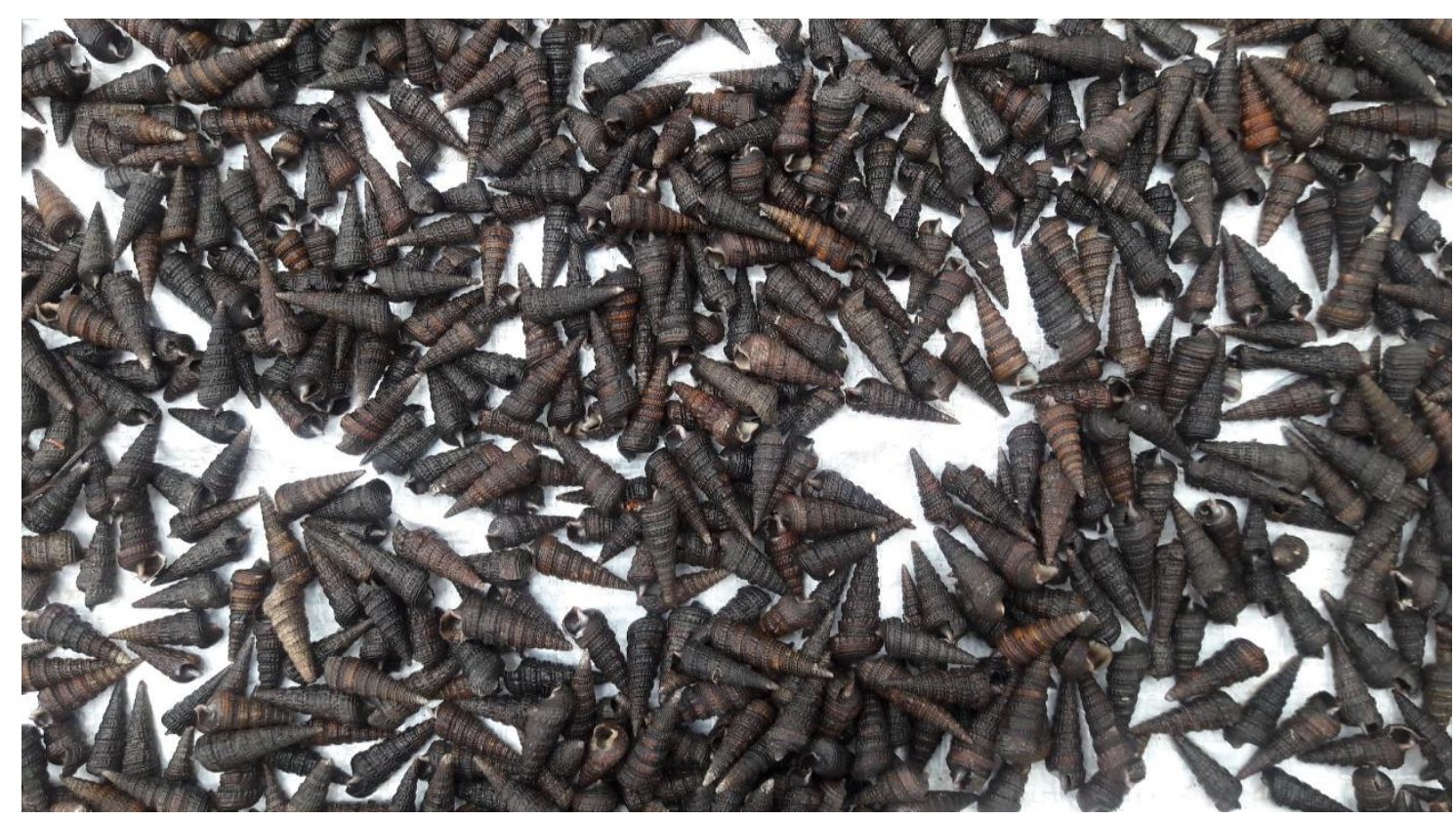

Plate 1: Periwinkle shells

[38-40] studied the extend periwinkle shell could be use as partial replacement of fine and coarse aggregates in concrete and sancrete block production. An increase in material development research has led to the use of periwinkle shells as aggregates in concrete production. However, in areas where stones are scars periwinkle shells have been used for purposes such as paving of water logged areas, construction of light-weight concrete etc. There are still larger amount unused periwinkle shells adding to environmental problems in areas where its economic value have not been discovered. Crave for an alternative stabilizer either partially or wholly replacement, cheaper, suitable, ecofriendly and readily available other than Ordinary Portland Cement remained the motivation for this research work. It is in line with this established background, this research seeks to investigate the potential of periwinkle shells as a stabilizing materials for lateritic soil.

\section{Materials and Methods}

Materials: The materials used for this study were

- Periwinkle Shells

- Ordinary Portland Cement (42.5 N) Expansive soils

- Water

\subsection{Materials}

Periwinkle shells were obtained from market women at the Sunday market Ogba. Lagos State, Nigeria. The shells were thoroughly washed in warmed water to removed traces of the periwinkle oysters from the shells, the washed periwinkle shells was sun dried and oven dried at $110^{\circ} \mathrm{C}$ to ensure complete dryness after which it was milled to powder. The resulting powder was sieved through $75 \mu \mathrm{m}$ to obtain fine powder. It was ensure that the Periwinkle Shell powder is kept air tight before and after use to prevent contaminations through moisture and others materials in the atmosphere. 
Lateritic soil was obtained from Mesan Village along Oko-Omi at Iju-Ota, Ado-Odo municipality, of Ogun State and stored in jute bags and taken to the geotechnical laboratory at the Civil Engineering Department, Covenant University, Ota. The lateritic soil was collected at a depth not less than one metre below the natural ground level indicating the sampling depth and date of sampling. [41] BS EN 1008 specification for clean water was considered for the experimental procedure. According [42 BS EN 1997-1 42.5 N grade of Ordinary Portland Cement (OPC) Dangote Cement brand was used for the experiment. The apparatus and tools used for the experimental process include: Atterberg limit apparatus, Pestle and mortar, Casagrande apparatus, Sieves of different diameters, thermostatically oven, digital weighing balance, moisture content can and led, shovel, hand trowel, head pan, and bucket.

\subsection{Methods}

The lateritic soil sample was dried for 5 days to allow for rapid elimination of its natural water which could affect the experimental procedure, the sample was then sieved using sieve size $4.75 \mathrm{~mm}$ to obtain the final soil sample for the tests. Preliminary tests like natural moisture content, and Atterberg's limits were carried out on the soil for easy identification and classification purposes.

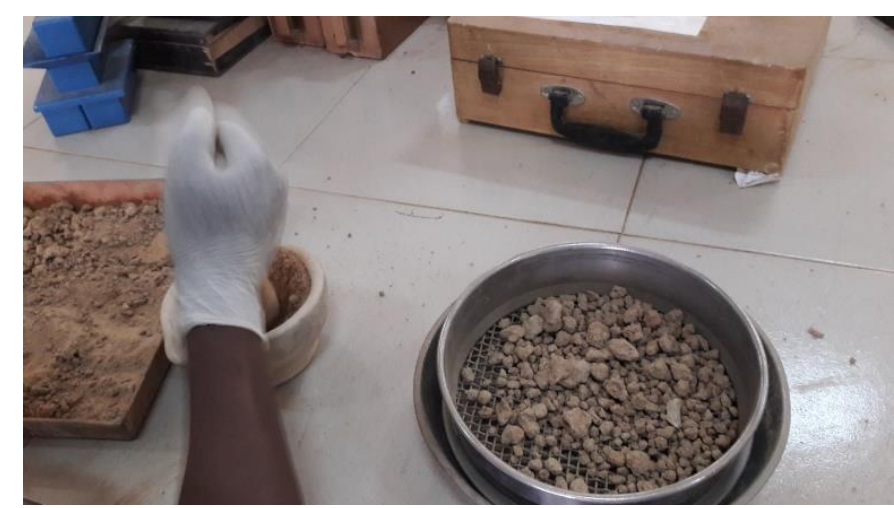

Plate 2: Sample Preparation

The experimental procedures were carried out in two different stages. Firstly, Ordinary Portland Cement (OPC) was added to the soil samples at $(2,4,6,8$ and $10 \%)$ by weight of the soil sample. Atterberg's limits (Liquid limit, plastic limit, plasticity index and shrinkage limit of soil passing BS $425 \mu \mathrm{m}$ sieve. Then, followed by Compaction test in accordance with [44] ASTM D698-12e2 and California bearing ratio (CBR) test based on [45] ASTM D1883-16 on the stabilized samples.

Secondly, the stabilization process was repeated using Periwinkle Shell Powder (PSP) on the soil samples at $(2,4,6,8$ and $10 \%)$ by weight of the soil. Atterberg's limits test, Compaction, California bearing ratio (CBR), tests were also repeated, while the result obtained using PSP as a stabilization agent was compared with the result obtained using OPC stabilizer. The laboratory test carried out put into consideration, the recommendations of [46-47] on safety knowledge and practices needed to for the experiments. The experiment on soil was performed according to British Standard methods of testing soil for Civil Engineering purposes (BS 1377: Part 1-9, 1990) [48]. Similar approach according to [49] was adopted in result presentation. 


\section{Results discussion}

Table 1 shown the results of the preliminary test on the engineering properties of lateritic soil sample without any stabilization agent added, the soil has a plasticity index of 7.6 and is classified as an A-4-5 from the AASHTO table of classification as it falls within the silt clay soil classification in the Unified Classification system. However, the liquid limit and plasticity index fall within the results of [11-14].

Table 1: Preliminary test on the engineering properties of lateritic soil

\begin{tabular}{|l|c|l|}
\hline S/n & Preliminary test summary of expansive soil sample & Value \\
\hline 1 & Natural Water Content & $28.0 \%$ \\
\hline 2 & Specific Gravity & $2.7 \%$ \\
\hline 3 & Liquid Limit & $28.0 \%$ \\
\hline 4 & Plastic Limit & $20.4 \%$ \\
\hline 5 & Plasticity Index & $7.6 \%$ \\
\hline 6 & AASHTO Classification & A-4-5 \\
\hline 7 & UCS (Unified Classification System) & Silt-Clay (SC) \\
\hline
\end{tabular}

Table 2 presented the chemical composition of Periwinkle Shell Powder (PSP) and Ordinary Portland Cement. The table showed that PSP is pozzolanic based on recommendation of [44] ASTM C618. The amount of chemical composition $\left(\mathrm{SiO}_{2}, \mathrm{Al}_{2} \mathrm{O}_{3}, \mathrm{CaO}\right.$ and $\left.\mathrm{Fe}_{2} \mathrm{O}_{3}\right)$ of Periwinkle Shell Powder were found to be above $90 \%$ which was higher than the $70 \%$ prescribed by [44]. PSP constituents' elements that could react with $\mathrm{CaO}$ to form permanent compounds in the presence of moisture, this is in line with [23-25] findings. The result also showed higher chemical composition over Milled Egg Shell (57 \%) and Rice Husk (81.5 \%) Ash used in stabilizing the geotechnical properties of the clayey and lateritic soil in [31-32] studies. However, there are remarkable similarities in the constituents' elements of OPC and PSP though the percentages composition differs, this accounts for the cementitious characteristics in PSP.

Table 2: Chemical composition of Ordinary Portland Cement (OPC) and Periwinkle Shell Powder (PSP)

\begin{tabular}{|c|c|c|c|}
\hline $\mathrm{S} / \mathrm{n}$ & Elemental oxides & Ordinary Portland Cement (OPC) \% & Periwinkle Shell Powder PSP \% \\
\hline 1 & $\mathrm{SiO}_{2}$ & 21.4 & 31.13 \\
\hline 2 & $\mathrm{Al}_{2} \mathrm{O}_{3}$ & 5.03 & 8.34 \\
\hline 3 & $\mathrm{Fe}_{2} \mathrm{O}_{3}$ & 4.40 & 4.21 \\
\hline 4 & $\mathrm{CaO}$ & 61.14 & 53.11 \\
\hline 5 & $\mathrm{MgO}$ & 1.35 & 0.76 \\
\hline 6 & $\mathrm{~K} 2 \mathrm{O}$ & 0.48 & 0.12 \\
\hline 7 & $\mathrm{Na}_{2} \mathrm{O}$ & 0.24 & 0.02 \\
\hline 8 & $\mathrm{TiO}_{2}$ & 0.37 & 0.03 \\
\hline 9 & $\mathrm{P}_{2} \mathrm{O}_{5}$ & 0 & 0.01 \\
\hline 10 & $\mathrm{SO}_{3}$ & 2.53 & 0.06 \\
\hline 11 & $\mathrm{LOI}$ & 1.29 & 2.43 \\
\hline
\end{tabular}

\section{Summary of the Atterberg limit tests}

Figures 1 and 2 shown the behaviour of lateritic soil treated with Periwinkle Shell Powder and Ordinary Portland Cement. The reduction in liquid limit of lateritic soil treated (OPC) was noticed at 
$6 \%$, plastic limit at $2 \%$ and plasticity index at $6 \%$ respectively. Meanwhile, (PSP) liquid limit dropped at 4 and $6 \%$, plastic limit dropped at $10 \%$ and plasticity index at $6 \%$ respectively. The finding of the study is similar to that of [27].

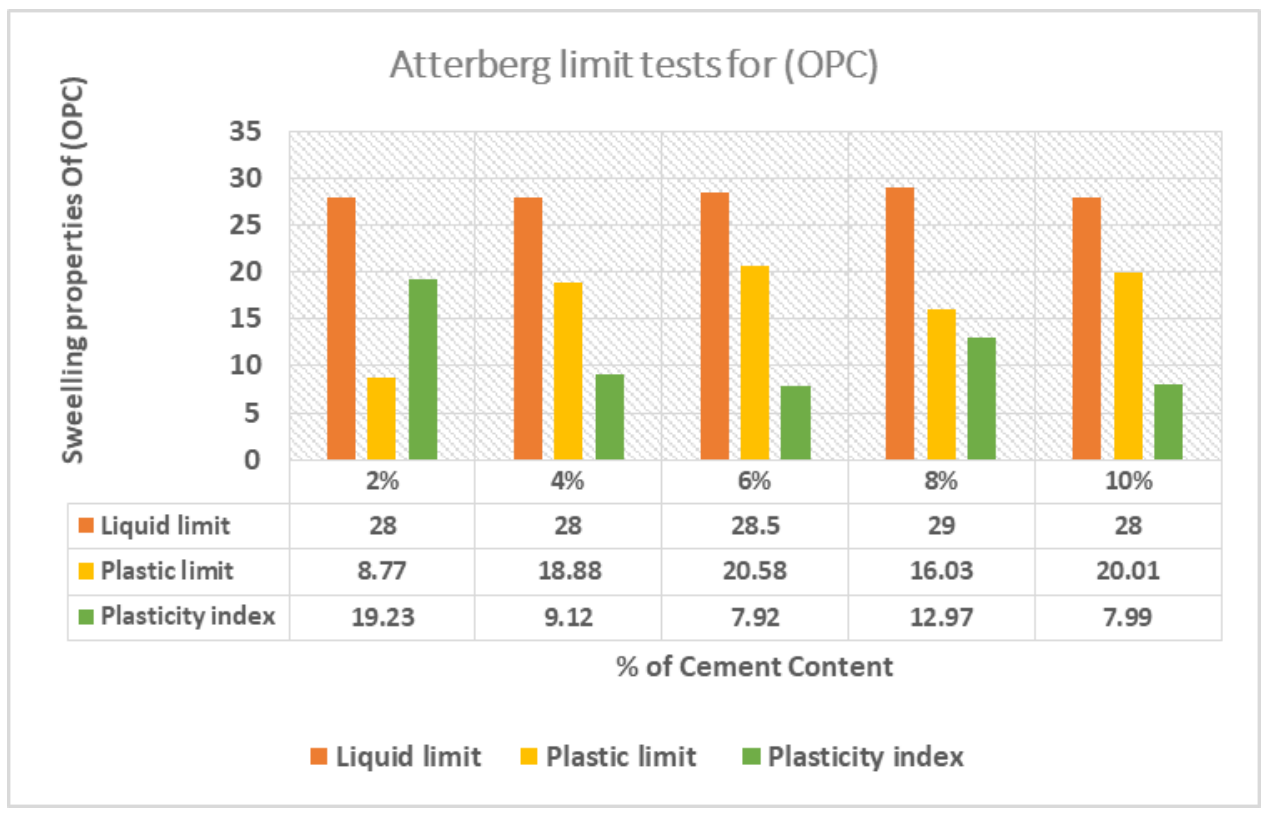

Figure 1: Behaviour of lateritic soil treated with Ordinary Portland Cement (OPC)

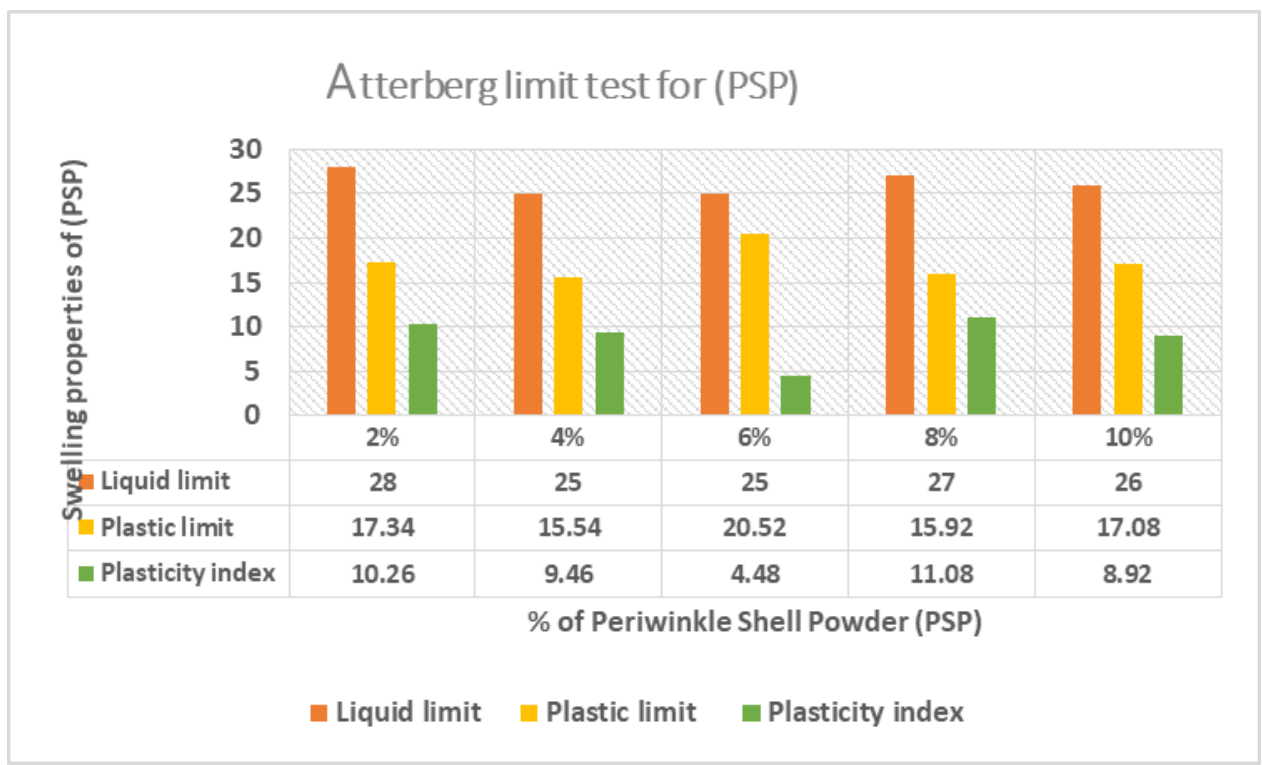

Figure 2: Behaviour of lateritic soil treated with Periwinkle Shell Powder (PSP)

Table 3 and figure 3 showed that the maximum dry densities of the lateritic soil increases as the percentages of the stabilization agent increases, however at 6\%, Periwinkle Shell Powder reached the peak MDD as further addition of $8 \%$ and $10 \%$ PSP led to a reduction in the soil MDD to $1892.46 \mathrm{~kg} / \mathrm{m} 3$ and $1867.80 \mathrm{~kg} / \mathrm{m} 3$ respectively. The trend is however different in OPC as the lateritic soil MDD kept increasing from $1895 \mathrm{~kg} / \mathrm{m} 3$ at $2 \%$ to $2294 \mathrm{~kg} / \mathrm{m} 3$ at $10 \%$ respectively showing that OPC remained a 
better stabilizing agent than the PSP. The graphical illustration of maximum dry density is as shown in Table 3, Figure 3 and 4 below.

Table 3: Summary of the compaction test

\begin{tabular}{|l|l|c|c|c|c|c|}
\hline S/n & $\begin{array}{l}\% \text { of } \\
\text { Cement } \\
\text { Stabilisation }\end{array}$ & $\begin{array}{l}\text { Cement Opt. } \\
\text { Moisture } \\
\text { Content }(\%)\end{array}$ & $\begin{array}{l}\text { Cement Max. } \\
\text { Dry Density } \\
\left(\mathrm{Kg} / \mathrm{m}^{3}\right)\end{array}$ & $\begin{array}{l}\text { \% PP } \\
\text { Stabilisation }\end{array}$ & $\begin{array}{l}\text { PSP Opt. } \\
\text { Moisture } \\
\text { Content }(\%)\end{array}$ & $\begin{array}{l}\text { PSP Max. } \\
\text { Dry Density } \\
\left(\mathrm{Kg} / \mathrm{m}^{3}\right)\end{array}$ \\
\hline 1 & 2 & 12.65 & 1895.95 & 2 & 11.72 & 1883.63 \\
\hline 2 & 4 & 13.08 & 1957.17 & 4 & 12.62 & 1908.40 \\
\hline 3 & 6 & 13.71 & 1994.41 & 6 & 13.58 & 1994.96 \\
\hline 4 & 8 & 14.68 & 2170.15 & 8 & 13.74 & 1892.46 \\
\hline 5 & 10 & 15.83 & 2294.48 & 10 & 14.41 & 1867.8 \\
\hline
\end{tabular}

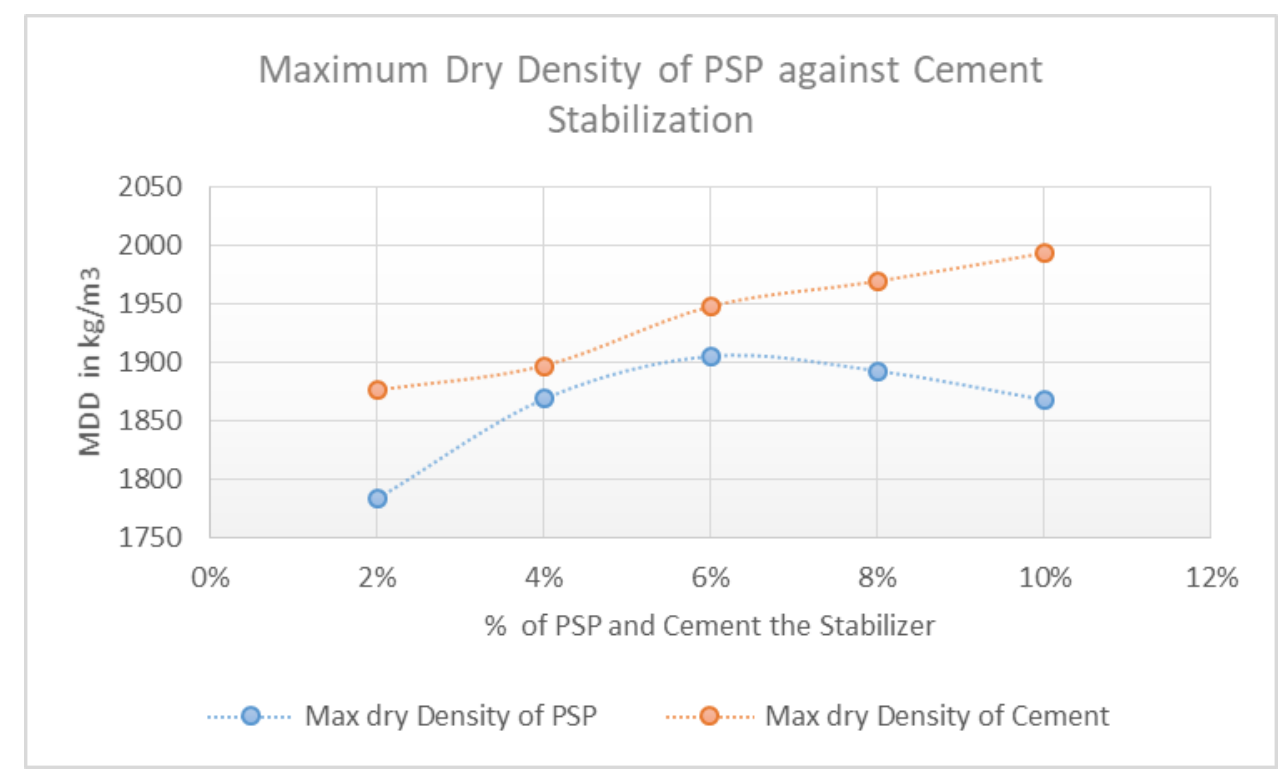

Figure 3 Maximum dry density of PSP and Cement stabiliser

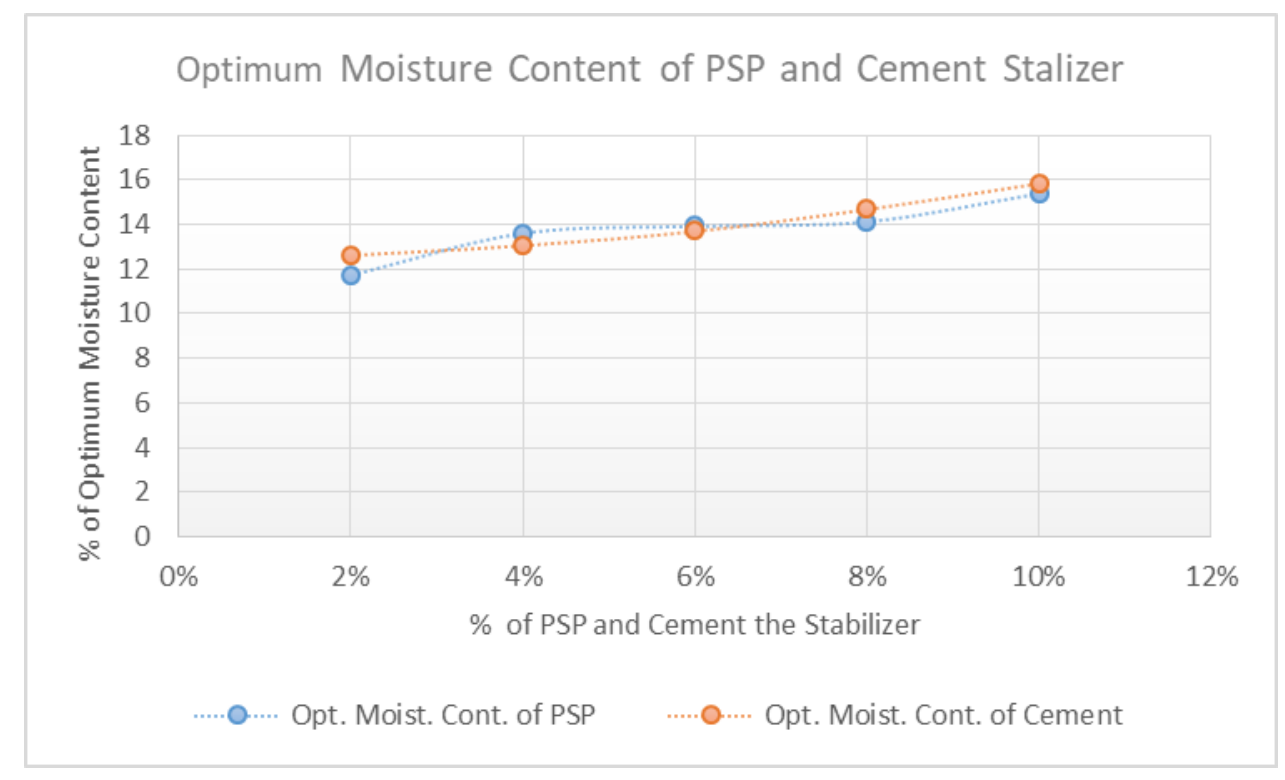


Figure 4: Optimum moisture content of PSP and Cement stabiliser

The results of CBR test as shown in Table 4 and Figure 5 below, The CBR values at 2.5mm penetration was adopted as the CBR values of the lateritic soil stabilized based on standard practice and since they have higher values. Both Periwinkle Shell Powder and Ordinary Portland Cement showed an increase in the CBR value of the lateritic soil tested indicating capacity to stabilize the soil. PSP CBR recorded an increase of $5.6 \%$ while OPC CBR recorded an increase of $34 \%$.

Unlike OPC whose CBR value gave continuous increase at each points of addition $(2,4,6.8,10 \%)$ of OPC stabilizer, compared with PSP that attained the maximum CBR value at the addition of $6 \%$ of PSP before the CBR value fall at 8-10\%.

Table 4: Summary of the CBR test

\begin{tabular}{|c|c|c|c|c|c|}
\hline$\% P S P$ & $2.5 \mathrm{~mm}$ & $5.0 \mathrm{~mm}$ & $\%$ OPC & $2.5 \mathrm{~mm}$ & $5.0 \mathrm{~mm}$ \\
\hline 2 & 0.43 & 0.43 & 2 & 0.99 & 0.87 \\
\hline 4 & 0.47 & 0.46 & 4 & 1.24 & 1.22 \\
\hline 6 & 0.53 & 0.49 & 6 & 4.67 & 4.44 \\
\hline 8 & 0.3 & 0.29 & 8 & 5.11 & 5.06 \\
\hline 10 & 0.34 & 0.34 & 10 & 5.76 & 5.6 \\
\hline
\end{tabular}

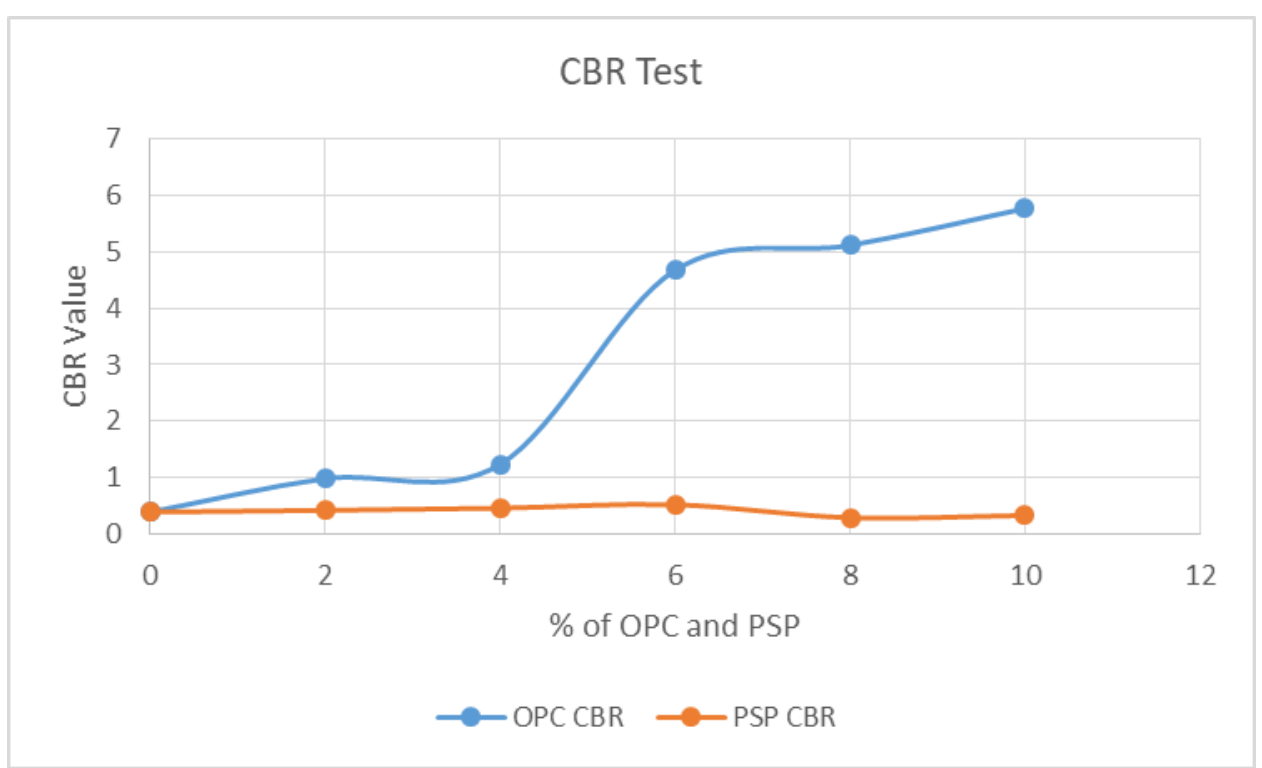

Figure 5: CBR value for PSP and OPC

\section{Conclusion}


The study thereby concluded that Periwinkle Shell Powder (PSP) could be considered as good stabilizer for clayey or lateritic, and its uses as a stabilizer could also provide a big relief to the environmental pollution caused by its indiscriminate dumping.

The following conclusions were highlighted in line with the findings of the study:

i) According to AASHTO and UCS classification, the lateritic soil used was classified as A-4-5 and Silt-Clay. An increase in the Atterberg limits of PSP stabilized lateritic soil and decrease in the plasticity index connote that the Periwinkle Shell Powder (PSP) is a good stabilizer.

ii) Meanwhile, it was noticed that the main mineral that characterized Ordinary Portland Cement (OPC) were $\mathrm{SiO}_{2}(24.0 \%), \mathrm{Al}_{2} \mathrm{O}_{3}(5.03 \%), \mathrm{CaO}(61.14 \%)$, and $\mathrm{Fe}_{2} \mathrm{O}_{3}(4.40 \%)$ they equals to $94.57 \%$. Compared to Periwinkle Shell Powder (PSP) that contained pozzolanic content of $\mathrm{SiO}_{2}(31.13 \%), \mathrm{Al}_{2} \mathrm{O}_{3}(8.34 \%), \mathrm{CaO}(53.11 \%)$, and $\mathrm{Fe}_{2} \mathrm{O}_{3}(4.21 \%) 90.54 \%$ in additions.

iii) A progressive increase in the Maximum Dry Density (MDD) of the soil sample stabilized with PSP from $2 \%(1875 \mathrm{~kg} / \mathrm{m} 3)$ to $10 \%(2294 \mathrm{~kg} / \mathrm{m} 3)$ respectively. This represent $22 \%$ increase in the MDD from the un-stabilized state. For PSP, the Maximum MDD was attained at $6 \%$ PSP $(1974 \mathrm{~kg} / \mathrm{m} 3)$, representing $5.3 \%$ increase in MDD of the soil from the un-stabilized state.

iv) Also for both stabilizing agent the Optimum Moisture Content (OMC) increases from $13.65 \%$ to $13.83 \%$ and from $11.72 \%$ to $14.41 \%$ for Cement and Periwinkle Shell Powder respectively. For PSP CBR from $5.8 \%$ to $19.7 \%$.

References:

[1] Braja, M. Das Principles of Foundation Engineering $7^{\text {th }}$ Edition. Centage Publisher 2011.

[2] Oyelami C.A.; Van Rooy J.L. A review of the use of lateritic soils in the construction/development of sustainable housing in Africa: A geological perspective. J. African Earth Sci. 2016 Jul 1, (119) 226-237.

[3] Luis Gonzalez V., Mercedes F. Geological Engineering, 2011 Taylor \& Francis. 0415413524, 978041541352. Pp. 700

[4] Ola, S.A. Geotechnical properties and behaviour of some stabilized Nigerian lateritic soils, Q. J. Eng. Geol. Hydrogeol. 1978, 11. 145-160, doi:http://dx.doi.org/10.1144/gsl.qjeg.1978.011.02.0 4.

[5] Ameta N.K.; Purohit, D.G.; Wayal A.S. Characteristics, problems and remedies of expansive soils of Rajasthan, India. EJGE. 2007, 13.

[6] Petty, T.M.; Little, D.N, "Review of Stabilization of Clays and Expansive soils I Pavement and Lighlty Loaded Structures-History, Practise, and future" ASCE J. Mater. Civ. Eng. 2002, 14, (6) 447-460.

[7] Babu, R.D.; Ramu, K.; Hassan, S.k; Kumar, G.K. A Study on the Swelling Behaviour of Expansive Soil Treated with Vitrified Polish Waste (VPW) and lime. Proceeding of $50^{\text {th }}$ Indian Geotechnical Conference, $17^{\text {th }}-19^{\text {th }}$ December 2015, Pune, Maharashtra, Indian. 
[8] Mitchell J.K. Practical problems from surprising soil behaviour: $20^{\text {th }}$ Terzaghi Lecture J. Geotechnical Engineering. Amer. Soc. Civ Engr. 1986, 112, (3) 253-289.

[9] Abdulfatai, I.A; Okunlola, I.A; Akande, W.G; Momoh, L.O.; Ibrahim, K.O. Review of gully erosion in Nigeria: causes, impacts and possible solutions. Journal of Geosciences and Geomatics. 2014; 2(3): 125-129.

[10] Ogunbayo BF, Ajao AM, Ogundipe KE, Joshua O, Durotoye TO, Bamigboye GO. Study of aggregate dormancy and its effects on the properties of aggregates and concrete. Cogent Engineering. 2018, 5: 1519944, https://doi.org/10.1080/23311916.2018.1519944

[11] Nwaiwu C.M.O; Alkali I.B.K; Ahmed U.A. Properties of ironstone lateritic gravels in relation to gravel road pavement construction. Geotech Geol Eng 2006; 24 :283-98.

[12] Badmus B.S. Plasticity and compressibility characteristics of lateritic soil from south western Nigeria. J. Nat Sci. Eng. Tech .2010;9 (1):14-22.

[13] Quadri H.A.; Adeyemi O.A.; Olafusi O.S. Investigation of the geotechnical engineering properties of lateritic as a subgrade and base material for road constructions in Nigeria. Civil Environ Res 2012; 2 (8):23-31.

[14]Eluozo S.N.; Nwaobakata C. Predictive models to determine the behaviour of plastic and liquid limit of lateritic soil for road construction at Egbema: Imo state of Nigeria. Int J Eng Technol 2013; 2 (1) :25-31.

[15] Osula D.A.O. A comparative evaluation of cement and lime modification of laterite. Eng Geol. 1996, 42: 71-81.

[16] Odoeyo, F.F.; Udeme, I.H.; Obusi, O.O. Strength performance of lateralized concrete. Constr Build Mater 2006, 20 (10):1052-1060

[17] Amu, O.O; Adetuberu, A.A Characterisitics of Bamboo Leaf Ash Stabilization on Laterite Soil in Highway Construction" Int. J. Eng. \& Technol. 2010,2(4)

[18] Oyediran, A.I.; Kalejaye, M. "Effect of Increasing Cement Content on Strength and Compaction Parameters of some Lateritic Soil from Southwestern Nigeria," EJGE 2011, 16.

[19] Sherwood P., Soil Stabilization with Cement and Lime. State of the Art Review. Transport Research Laboratory HMSO, London 1993.

[20] Amu, O.O.; Fajobi, A.B.; Oke, B.O. "Effect of Egg shell powder on stabilizing potential of lime on an expansive clay soil. J. of Appl. Sci.5 (8) ISSN 18125654

[21] Owolabi T.A.; Aderinola O.S. An Assessment of Renolith on Cement-Stabilized Poor Lateritic Soils. Sci-Afric J. Scientific Issues, Research and Essays. 1st Academia Publishing London. 2014, 2 (5)

[22]Zumrawi, M.M.E. Stabilization of Pavement Subgrade by Using Fly Ash Activated by Cement. Amer. J. Civ. Eng. Archit. 2015, 3 (6). 
[23] Olusola, K.O.; Umoh A.A. "Strength Characteristics of Periwinkle Shell Ash Blended Cement Concrete." Inter J. Archit Eng \& Const 2012, 1 (4), 213-220

[24] Offiong, U.D.; Akpan, G.E. Assessment of Physico-Chemical Properties of Periwinkle Shell Ash as Partial Replacement for Cement in Concrete. Assessment. Int'1. J. Scienti Eng. Sci. 2017;1 (7) 33-36.

[25] Attah, I.C.; Etim, R.K.; Ekpo D.U. Behaviour of periwinkle shell ash blended cement concrete in sulphuric acid environment. Nig. J. Technol. 2018, 37 (2): 315-21.

[26] Durotoye T.O; Akinmusuru J.O; Ogbiye A.S; Bamigboye G.O. Effect of Common Salt on the Engineering Properties of Expansive Soil". Int. J. Eng. \& Technol. 2016, 6(7)

[27]Durotoye, T.O.; Akinmusuru, J.O.; Ogundipe, K.E. Experimental datasets on engineering properties of expansive soil treated with common salt. Data in Brief. 2018, 18, 1277-1281. https://doi.org/10.1016/j.dib.2018.04.038

[28]Rahman, M.A. Properties of clay-sand-rice husk ash mixed bricks. Int. J. Cet Comp. Ligt. Con.; 1987. 9 (2):105-108

[29] Oyekan, G.L.; Kamiyo, O.M. A study on the engineering properties of sandcrete blocks produced with rice husk ash blended cement. J. Eng. Techn Res, 2011, 3 (3), 88-98.

[30] Oyetola, E.B.; Abdullahi, M. The use of rice husk ash in low-cost sandcrete block production. Leonardo Elect J. Prac. Technol 2006. 8(1), 58-70.

[31]Joshua, O.; Ogunde, A.O.; Omuh, I.O.; Ayegba, C.; Olusola, K.O., (2015). Exploring the Pozzolanic Potential of Blend of Palm Kernel Nut Ash (PKNA) with Cement towards a sustainable construction. Proceedings of the 2nd Covenant University International Conference on African Development Issues (CU-ICADI) 2015: Materials Technology Track. (2) $135-140$

[32] Joshua, O.; Olusola, K.O.; Fagbenle,O.I.; Olawuyi, B.J.; Adebayo, L.; Ogunde, A.O.; Afolabi, A.O.; Olorunsola, S.M. "Pulverized Calcined Clay and Carbide Waste as Alternative Binder in Concrete and Mortar Applications for Sustainable Construction." 2018, 675-684.

[33] Oluwatuyi, O.E.; Adeola, B.O.; Alhassan, E.A.; Nnochiri, E.S., Modupe, A.E.; Elemile, O.O.; Obayanju, T.; Akerele, G. Ameliorating effect of milled eggshell on cement stabilized lateritic soil for highway construction. Case Studies in Constr. Mat. 2018, 1;9:e00191.

[34]Rahgozar, M.A.; Saberian, M.; Li, J. Soil stabilization with non-conventional eco-friendly agricultural waste materials: An experimental study. Transt. Geot. 2018.14, 52-60.

[35] Abioye, T., Oyesomi, K., Ajiboye, E., Omidiora, S. \& Oyero, O. (2017). Education, Gender, and Child-Rights: Salient Issues in SDGS Years in ADO-ODO/OTA Local Government Area of Ogun State, Nigeria in Okorie, N., Ojebuyi, B. \& Salawu, A. (eds.) Impacts of the Media on African Socio-Economic Development. (pp. 141-154) Hershey PA, USA: IGI Global. 
[36] Oyesomi, K.O, Salawu, A. \& Olorunyomi, B. (2017). Indigenous Communication: SocioEconomic Characteristics Influencing Contemporary Female Political Participation. Journal of International Women Studies (JIWS). Vol 18, no 4, PP.164-181.

[37] Oyero, O. S., Oyesomi, K. O, Abioye, T, Ajiboye E, \& Kayode-Adedeji K.T. (2018). Strategic communication for climate change awareness and behavioural change in Ado-Odo/Ota Local Government of Ogun State. African Population Studies Vol 32, No 1, (Supp.), 2018.

[38] Agbede, O. I., \& Manasseh, J. Suitability of periwinkle shell as partial replacement for river gravel in concrete. Leonardo Electronic J. Prac. Techn. 2009) 15(2), 59-66.

[39] Otunyo, A.W.; Friday, I.U.; Israel, T.A. Exploratory study of crushed periwinkle shell as partial replacement for fine aggregates in concrete. Scientia Africana, 2014, 13(1), 151-159.

[40] Soneye, Timothy, Anthony Nkem Ede, Gideon Bamigboye, and David Olatunde Olukanni. "The study of periwinkle shells as fine and coarse aggregate in concrete works." 2016, 361-364.

[41]BS EN 1008, British Standard Institution Methods of test for water for making concrete, British Standard Institution, London. 2002

[42] BS EN ISO 10545-3:1997 - Ceramic tiles. Determination of water absorption, apparent porosity, apparent relative density and bulk density.

[43] ASTM C618, Standard Specification for Coal Fly Ash and Raw or Calcined Natural Pozzolan for Use in Concrete, American Society for Testing and Materials, ASTM International, West Conshohocken, PA, 2003.

[44] ASTM D698-12e2. Standard test methods for laboratory compaction characteristics of soil using standard effort (12 $400 \mathrm{ft}-\mathrm{lbf} / \mathrm{ft} 3(600 \mathrm{kN}-\mathrm{m} / \mathrm{m} 3))$. West Conshohocken, PA: ASTM International; 2012.

[45] ASTM D1883-16. Standard test method for California Bearing Ratio (1CBR) of laboratorycompacted soils. West Conshohocken, PA: ASTM International; 2016.

[46] Ogundipe, K.E; Ogunde, A.O; Olaniran, H.F; Ajao, A.M.; Ogunbayo, B.F; Ogundipe, J.A. Missing Gaps in Safety Education and Practices: Academia Perspectives. Int. J. Civ. Eng. T echnol. 2018, 8(11),http://www.iaeme.com/IJCIET/issues.asp?JType=IJCIET\&VType=8\&IType= $\underline{11}$

[47] Ogundipe, K.E.; Ogunbayo, B.F.; Ajao, A.M.; Ogundipe, U.L.; Tunji-Olayeni, P.F. Survey datasets on categories of factors militating against safety practices onconstruction sites. Data in Brief, 2018, 19, 2071-2078. https://doi.org/10.1016/j.dib.2018.06.101

[48]British Standard 1377, Methods of Test for Soils for Civil Engineering Purposes, British Standard Institution, London, 1990.

[49] Ajao, A.M., Ogunbayo, B.F., Ogundipe, K.E., Joshua, O., Olofinnade, O.M., 2018. Experimental datasets on properties of river sand as an aggregate in replacement of crushed rock for interlocking stones production. Data in Brief 20, 602-608. doi:10.1016/j.dib.2018.08.056 